\title{
MANAGEMENT OF SQUASH MOSAIC DISEASES IN NEW ZEALAND
}

\author{
J.D. FLETCHER ${ }^{1}$, T.J.B. HERMAN ${ }^{2}$, R.A. LISTER ${ }^{1}$, R.C. BUTLER ${ }^{1}$ \\ AND G.R. TRAVIS ${ }^{1}$
}

\author{
${ }^{1}$ New Zealand Institute for Crop \& Food Research Limited, PB 4704, Christchurch \\ ${ }^{2}$ FruitFed Supplies, Hastings \\ Corresponding author: fletcherj@crop.cri.nz.
}

Buttercup squash (Cucurbita maxima Duch.) is an important export crop in New Zealand with annual production reaching 130000 tonnes. The important mosaic diseases of buttercup squash in New Zealand are caused by Watermelon mosaic virus 2 (WMV2) and Zucchini yellow mosaic virus (ZYMV). The discovery of ZYMV in Hawke's Bay has focussed research on understanding pathogen epidemiology. Crop surveys determined that weed species and volunteer squash hosted ZYMV and WMV2, and that aphids initiated infections from these plants. The weed families of greatest importance in this process were identified by analysis of Pearsons correlation coefficients. In early squash sowings, correlations between virus presence and subsequent virus incidence was high in Chenopodiaciae and Lamiaciae. Other factors associated with incidence of mosaic diseases included adjacent squash crops, a history of previous infection and adjacent home gardens. To help growers manage disease outbreaks we initiated an aphid monitoring programme using a suction trap. Growers receive weekly trap figures and virus incidence observations by fax, mail or a web page (www.aphidwatch.com/squash/). The web page also presents information on the viruses, aphid vectors, weeds and other aspects of disease control to provide squash growers with up-to-date information on management of mosaic diseases.

\section{NEW ZEALAND NATIVE APHIDS}

\author{
D.A.J. TEULON ${ }^{1}$, M.A.W. STUFKENS ${ }^{1}$, C.D. von DOHLEN ${ }^{2}$ and \\ J.M. KEAN ${ }^{3}$ \\ ${ }^{1}$ Crop \& Food Research, Private Bag 4704, Christchurch, NZ \\ ${ }^{2}$ Department of Biology, Utah State University, Logan, Utah 84322, USA \\ ${ }^{3}$ AgResearch, Biocontrol and Biodiversity Group, PO Box 60, Lincoln, NZ \\ Corresponding author: teulond@crop.cri.nz
}

Of the approximately 120 aphid species in New Zealand only about 12 are indigenous. In recent years, there has been increased scientific interest in these native insects for three main reasons. Firstly the impacts of introduced biological control agents on the indigenous fauna are being investigated. Secondly, factors leading to the rarity of these and other organisms are being explored. The third reason is to elucidate the evolution and biogeography of aphids in a global context. Consequently, intensified field surveys have been undertaken and the existence of at least six new native species has been confirmed or discovered in the last six years. There is also evidence for the existence of several other species. The New Zealand native aphid fauna now includes Aphis coprosmae, A. cottieri, A. healyi, A. nelsonensis, Aphis sp. (on Olearia), Paradoxaphis aristoteliae, P. plagianthi, Casimira sp. (on Ozothamnus), Euschizaphis sp. (on Dracophyllum), Euschizaphis (on Aciphylla), Neophyllaphis totarae and Sensoriaphis nothofagi. 